\title{
APRESENTAÇÃO DO DOSSIÊ DITADURA MILITAR NO BRASIL
}

\section{Organizadores:}

\author{
DANIELA MOURA ROCHA DE SOUZA \\ UNEB, campus VI - Caetité - BA \\ profadanymoura@gmail.com
}

JOSÉ ALVES DIAS

UESB - Vitória da Conquista - BA

jose.dias@uesb.edu.br

O dossiê Ditadura Militar no Brasil é o resultado da contribuição de pesquisadores brasileiros sobre um período histórico bastante delicado, que possui interfaces com o presente, não obstante, o passado ainda seja nebuloso. Após o golpe de 1964, que depôs o presidente João Belchior Marques Goulart, que assumiu após a renúncia do titular Jânio da Silva Quadros, foram 21 anos de ditadura, tendo à frente os comandantes militares e em seu entorno civis de variados segmentos sociais. Foram décadas de intervenções autoritárias no sistema educacional, cassações de direitos políticos e profissionais, perseguições, prisões ilegais, torturas e assassinatos de opositores, sob a alegação do anticomunismo.

Infelizmente, nos anos subsequentes a tal barbárie, os responsáveis não foram punidos, em função de manobras jurídicas para a concessão da Lei de Anistia, em 1979, e das conciliações pelo alto que dificultaram o reconhecimento da responsabilidade do Estado, as reparações de danos, as concessões de indenizações e o conhecimento pleno dos fatos pelo conjunto da sociedade. Por tais razões, o esforço constante de revelar integralmente o passado foi substituído, paulatinamente, por um revisionismo histórico que terminou por relativizar a crueldade do processo autoritário e abrir caminhos para uma memória fragmentada e lacunar da ditadura no Brasil.

Como observou Karl Marx, a história se repete como farsa e tragédia, na medida em que, atualmente, o conservadorismo autoritário vem conquistando espaços e uma parcela significativa da sociedade está defendendo o retorno aos ideais postulados em 1964 e às práticas ditatoriais, criminalizando os movimentos sociais e as matrizes do pensamento crítico, retomando o antigo discurso da crise econômica e evocando novamente o espectro comunista para justificar as medidas de cunho fascista, tais como a "Escola sem Partido", que estabeleceu a censura como método de reestruturação em todos os níveis educacionais.

Diante disso, a reescrita da história está ocorrendo sob os auspícios daqueles que praticaram crimes contra a humanidade. De modo semelhante, sobrevém o estrangulamento do ensino, a precarização da formação docente e o silenciamento das memórias sobre as formas mais hediondas de repressão, como também, a descaracterização das lutas de oposição nas décadas de 1960 a 1980.

Em função desse cenário, ao trazer como pauta o tema da ditadura no Brasil, a presente edição se torna essencial e oportuna, por ressaltar temas que não podem ser esquecidos. O dossiê ressalta, sobretudo, a originalidade e relevância das temáticas propostas por pesquisadores e pesquisadoras acerca do processo ditatorial brasileiro, entre 1964 e 1985, a fim de compor uma memória histórica crítica de um período tão polêmico e tão controverso em nossa história. 
Á guisa de introdução, o artigo de José Luís Sanfelice Repressão e resistências no Brasil: século XX, apresenta um estudo tomando os anos de 1970 como um movimento da história determinado por tensões que opuseram diferentes sujeitos sociais em conflitos de pensamento, no contexto da reforma universitária na qual por um lado tínhamos o discurso oficial da reestruturação pronunciados por Flávio Suplicy de Lacerda (Ministro da Educação e Cultura) e Raymundo Moniz de Aragão como porta voz do V Fórum Universitário, concentrando-se na defesa de uma reforma consentida e de outro o contraponto crítico da resistência tendo como um de seus principais intérpretes Florestan Fernandes; na sequência Patrícia Sposito Mechi apresenta na Arqueologia e história da repressão na ditadura militar brasileira: alguns aspectos sobre a guerrilha do Araguaia, a necessidade de estudos interdisciplinares sobre casos como a guerrilha do Araguaia, considerando a lacunar e fragmentária documentação existente, ocultação de fontes históricas, provenientes de uma política repressiva, destacando o papel da Comissão Nacional da Verdade e as dificuldades encontradas por esta devido a dispersão de acervos.

Em seguida o artigo Dissonâncias à esquerda: a POLOP, o golpe e a ditadura militar de Eurelino Coelho, traz uma análise de documentos que registraram a atuação da POLOP durante a ditadura de 1964, como uma organização singular de matriz marxista que formulou estratégias alternativas a do PCB, com outras opções táticas durante os vários momentos do regime ditatorial. Carlos Nássaro Araújo da Paixão, no texto A experiência diplomática de Juraci Magalhães: a política externa brasileira após 1964 e a assinatura dos tratados de Lisboa, traz a atuação do ministro das Relações Exteriores, Juracy Magalhães, entre janeiro de 1966 e março de 1967, período em que esteve nesse cargo, a fim de demonstrar o processo de redefinição da política externa brasileira pós 1964, o entrelaçamento com os EUA, e os vínculos estabelecidos com Portugal, a partir da análise de acordos formais expedidos pelo chanceler brasileiro e seu congênere português Franco Nogueira.

Saindo dos gabinetes oficiais para os porões da ditadura, Deborah Regina Leal Neves apresenta em DOI-CODI II Exército: a experiência de preservação de um patrimônio sensivel, a perseguição deflagrada pelo DOI-CODI, que legou uma série de assassinatos e torturas aos opositores da ditadura, ressaltando a defesa pela preservação do prédio que abrigou essa instituição, tomando-o como patrimônio histórico, e a importância de se tomar a sua história a fim de denunciar uma série de crimes cometidos contra a humanidade, silenciados pelas conduções políticas do país. Outra denúncia é feita por Ana Maria Colling, em Vozes silenciadas: a ditadura brasileira e as mulheres, na qual a autora enfatiza a repressão ocorrida pelo processo ditatorial, e como as mulheres militantes sofreram duplamente a repressão pelo fato de serem consideradas comunistas e também por sua condição de gênero. Também ressaltando processos de lutas e repressão social, Antônio Maurício de Freitas Brito, traz em O Movimento estudantil universitário no Brasil: entre a luta pela reforma universitária e a resistência à ditadura (1960-1968), a atuação do movimento estudantil dos anos de 1960, apresentando suas pautas de lutas, sobretudo a resistência com a reforma universitária implantada pelo regime em 1968 aos moldes MEC-USAID, e os desdobramentos desta que levou a ditadura militar a tratar os encontros estudantis como questão de "polícia".

Para além dos cenários da educação formal, a igreja católica também se posicionou dubiamente, entre a repressão e a resistência, na qual Grimaldo Carneiro Zachariadhes, em D. Eugênio Sales na arquidiocese de Salvador em tempos de ditadura militar, analisa a trajetória do arcebispo D. Eugênio Sales, entre os anos de 1964 até 1971, como o responsável pela reestruturação da arquidiocese, enfrentando conflitos com os membros do clero e leigos devido a sua posição diante do regime militar. E finalmente, Lucileide Costa Cardoso, faz uma importante análise acerca de nosso contexto atual com o artigo Volta à ditadura? Retorno da utopia autoritária presente nas memórias de militares e civis de 1964, no qual recupera a produção sobre o tema difundida entre os anos de 1980 e 1990, e como se dá a batalha da memória brasileira que tem fragilizado a narrativa das vítimas 
do regime ditatorial, e ressaltando o movimento da intervenção militar já, como solução da atual crise político-econômica e social que temos experienciado e a ascensão de novos agentes autoritários como representantes do poder.

O dossiê retoma temas consolidados na historiografia brasileira para vislumbrar novas perspectivas e propor uma postura de resistência às práticas fascistas. Que tais leituras, elaboradas com seriedade e dedicação, possibilitem a emergência de debates profícuos e aprofundados diante de tais circunstâncias desafiadoras nas quais é preciso afastar o "cale-se". 